made in regard to the work being done. But, as was pointed out to the Committee, the Council, in its recent booklet, "The Agricultural Reseßrch Service", describing its activities, now claims to 'supervise' the State-aided research institutes. The Oxford Dictionary gives as one of the meanings of this word "to superintend", and this in turn means "to have or exercise the charge or direction of". Is this what the Council is aiming at ? The institutes have their own governing bodies chosen for their special knowledge of the subjects dealt with, and it would be a heavy loss if they were abolished or so weakened that no busy man would consider it worth while to serve on them. Sir William Ogg suggested that the happiest relation between the Council and the institutes would be that of the University Grants Committee to the universities, and this idea certainly seems worth following up. Alternatively, the relationship of the Medical Research Council to its institutes might be worth studying. The Committee took it for granted that the large Government grants necessarily entailed loss of independence; but claims that "the system of direct administration by the Agricultural Research Council promoted greater flexibility both of administration and of the research programmes". The Committee expressed its belief that "this could be done without interfering with the supervision at present exercised by their Governing bodies". It all turns on what exactly is meant by "direct administration". One member of the Committee suggested that there should be on the Council a non-specialist "business brain" to "judge between what is necessary and what is not". Any attempt to do this could lead only to disaster.

Public expenditure on agricultural research is now on so large a scale that full inspection of accounts must be, and indeed is, willingly accepted. The great problem is to find a system that satisfies the canons of sound finance without interfering with the freedom of action essential to the proper conduct of scientific investigation. The Committee learned that Ministers have this under consideration and therefore felt precluded from bringing it within its purview. Our present system no doubt needs tidying up; but it has, in fact, worked without waste or inefficiency as the Committee recognizes, and, we may add, it has produced a volume of work that in its relation to the available resources will bear favourable comparison with any done elsewhere.

\section{SCIENCE AND LIFE}

The Nature of Science and Other Lectures By Edwin Hubble. Pp. viii $+83+2$ plates. (San Marino, Calif. : The Huntington Library, 1954.) 2 dollars.

$\mathbf{W}^{\mathrm{E}}$ owe to the Trustees and Friends of the Huntington Library this last testament of one of the greatest astronomers of our time. The six lectures contained in the book are divided into two groups-three on the nature and meaning of science, and three on scientists and war. Science to Edwin Hubble was the adventure in which man, equipped with his five senses, explores the universe around him. Unlike wisdom, which is peculiar to the individual, knowledge accumulates through the ages and can be passed on from one generation to the next. It piles up against some barrier, until a weak spot is found by an alert research worker, often one who is following a by-path which has stirred his curiosity. Exploration sweeps forward, guided by existing knowledge; old theories are revised, and new theories are formulated as temporary working hypotheses. New laws may be derived to be tested by further observation and experiment.

The success of the scientific method is illustrated by a quotation from George Sarton: "The saints of to-day are not necessarily more saintly than those of a thousand years ago : our artists are not necessarily greater than those of early Greece; they are likely to be inferior; and, of course, our men of science are not necessarily more intelligent than those of old; yet one thing is certain, their knowledge is at once more extensive and more accurate. The acquisition and systematization of positive knowledge is the only human activity that is truly cumulative and progressive".

A by-product of science is technology, the application of the results of science to the service of mankind. Hubble gives an account of the amazing growth of industrial research in the United States during the past thirty years. In this connexion he notes how expanding knowledge, which can be used for evil as well as good, has swept across the danger level, so that men are now in a position to wreck the civilization of the world. The last lecture in the book, "The War that must not happen", gives a grim account of what may take place if we leave our new knowledge at the disposal of traditional politics. Hubble was no pacifist. Before the days of Pearl Harbour, he was urging with all his might the duty of the United States to enter the Second World War and to pay whatever price was necessary to secure liberty for the world. It was with the utmost reluctance that, when war came, he obeyed orders to apply his scientific knowledge to problems of ballistics instead of returning to active service in the United States artillery. But he learnt at the Aberdeen Proving Ground what it meant to face the problems of active warfare unprepared : "The army would come to us with an urgent problem that had arisen in the actual fighting. I would say, 'We don't know, but of course we can find out'. 'Go ahead, find out', the army would say. 'All right. It will take so many men, so much equipment, so much time if we stop other work and give it priority'. 'Time', the army' would say, 'hell, we have to cable the answer to-night'."

It is clear that Hubble would have supported wholeheartedly research work to face in advance the problems of the next war, if it should come. But he clearly saw that the modern war of technology is suicide for both sides. War must be stopped if we are to enjoy the potential blessings of new knowledge. Hubble was clear that treaty agreements are not enough. He saw one possible solution-a world authority armed. with a police force for the strictly limited purpose of preserving order among the nations. It is the responsibility of all individuals to work to this end-to read up the subject, discuss it and urge the politicians to accept it. The necessity for decision and action is here and now. "We may not like the price, but it is cheap for what we buycivilisation and life itself." F. J. M. StratTon 